Article

\title{
The Use of Stable Water Isotopes as Tracers in Soil Aquifer Treatment (SAT) and in Regional Water Systems
}

\author{
Ido Negev ${ }^{1, *}$, Joseph Guttman ${ }^{1}$ and Wolfram Kloppmann ${ }^{2}$ \\ 1 Mekorot, National Water Company, Tel Aviv 6713402, Israel; yguttman@mekorot.co.il \\ 2 BRGM, French Geological Survey, Orleans, France; w.kloppmann@brgm.fr \\ * Correspondence: nido@mekorot.co.il; Tel.: +972-3-623-0653 \\ Academic Editor: Pieter J. Stuyfzand \\ Received: 31 October 2016; Accepted: 12 January 2017; Published: 24 January 2017
}

\begin{abstract}
This study examines the feasibility of tracing and quantifying the progress of different water sources along the water-effluent-SAT (Soil Aquifer Treatment) chain using ${ }^{2} \mathrm{H}$ and ${ }^{18} \mathrm{O}$ isotopes. The research was conducted at the Dan Region Reclamation Plant (Shafdan), which reclaims $\sim 135 \mathrm{MCM}$ /year of effluent for irrigation. Water samples representing different stages along the chain were taken in two surveys during 2010-2011 and 2014. $\delta^{18} \mathrm{O}$ and $\delta^{2} \mathrm{H}$ values were used for mixing ratios (MR) calculations, and compared with calculated MRs using chloride and carbamazepine concentrations. The results showed a relative enrichment of ${ }^{18} \mathrm{O}$ and ${ }^{2} \mathrm{H}$ in the Israeli water system compared to the regional groundwater, due to the addition of massive quantities of desalinated water. A linear correlation for $\delta^{2} \mathrm{H}$ vs. $\delta^{18} \mathrm{O}$ with a slope of 4.5 was found for the different freshwater sources and their mixing products, suggesting evaporation-mixing effects. MR values indicate on the spreading of new type of effluent originating from desalinated water in the aquifer. A dilution model explains the isotopic compositions in the water system and of the Shafdan effluents. Water isotopes have an advantage over other tracers, due to the ability to predict their ratio in the supply system and in the effluent, based on mass balance calculations and on knowledge of water supply volumes.
\end{abstract}

Keywords: stable water isotopes; SAT; desalination; effluent

\section{Introduction}

The use of stable isotopes as markers for tracing after the spreading, processes and reactions of various materials in the environment and the water cycle has been commonplace for many years $[1,2]$. The fractionation of the water molecule stable isotopes ${ }^{18} \mathrm{O} /{ }^{16} \mathrm{O}$ and ${ }^{2} \mathrm{H} /{ }^{1} \mathrm{H}$ under natural moderate temperature conditions is affected mainly by phase transformations, notably evaporation-condensation and freezing-melting processes due to temperature and pressure changes. This, together with their intrinsic association to the water molecule and their relatively inert behavior in other processes, makes these isotopes ideal for tracking different sources of water bodies during transport and mixing processes [1-3]. However, in many studies that applied the stable isotopes of water to assess contamination processes or managed aquifer recharge (MAR), only the qualitative or semi-quantitative aspects of "fingerprints" of mixing between different sources could be demonstrated (e.g., [4-7]). The main reason for this is the lack of unambiguous definition of end-member composition, which did not enable quantitative estimations. Specifically, in Israel, neither in the Shafdan plant nor in any other recharge (MAR) project, stable water isotopes have been used for mass balance calculations.

Water supply in Israel is broadly based on a centralized system known as the National Water Carrier (NWC). The NWC collects its water from three major natural water sources: Lake Kinneret (Sea of Galilee (SOG)) in the north, and the Coastal and Mountain aquifers in the central part of Israel. 
Collection and analysis of available $\delta^{18} \mathrm{O}$ and $\delta^{2} \mathrm{H}$ values published in various studies indicate that each of the abovementioned natural water sources has a typical isotope composition, as will be further discussed in the results section.

During the last decade, an important source of desalinated water has been added to the National Water Carrier as five new desalination plants went into action: Ashkelon (capacity of 120 million cubic meter per year [CM/year], 2005), Palmahim (45 MCM/year, 2007, and 90 MCM/year since 2013), Hadera (145 MCM/year, 2009), Soreq (150 MCM/year, 2013) and Ashdod (100 MCM/year, 2015). Thus, since 2015 desalinated water has contributed more than $60 \%$ of the water in the NWC, and has nearly reached $100 \%$ in the Dan Region during significant periods of the year. Previous studies have shown that the isotopic composition $\delta^{18} \mathrm{O}$ and $\delta^{2} \mathrm{H}$ of the raw, Mediterranean Sea water is preserved during the desalination process, and hence also characterizes the desalinated product [6-8].

The Dan Region Wastewater Reclamation Plant (Shafdan plant), established during the 1970s, provides a centralized, high quality solution for the sewage of the most populated area in Israel. The plant collects the sewage of the Tel-Aviv Metropolitan area (Dan Region) and neighboring municipalities, treats it, and afterwards recharges it into a defined coastal aquifer section for a complementary Soil Aquifer Treatment (SAT). In this way, the Shafdan plant treats about $135 \mathrm{MCM} /$ year of raw sewage from seven municipalities, industrial areas, and approximately 1.5 million inhabitants. The sewage is treated to a level of secondary effluents using a Mechanical Biological Treatment Plant (MBTP), prior to infiltration in the SAT ponds. The recharge and the SAT process takes place in the coastal Quaternary sandstone aquifer (the Coastal Aquifer), one of the major freshwater sources of Israel.

During flow process of the secondary effluent through the vadose zone and the aquifer, most of the biodegradable organic matter, suspended solids, bacteria, viruses, phosphorus, heavy metals and other ions are removed from the effluents by a combination of geochemical, physical, and biological processes (e.g., [9-17]). Retention time in the aquifer (saturated zone), estimated using a flow-transport numerical model developed and calibrated by Mekorot, ranges between 0.5 and 60 months, and is strongly dependent on the spatial flow regime and on the distances between the wells and their associated recharge ponds [17]. The aquifer section utilized for the SAT treatment is dynamically isolated from the nearby main coastal aquifer by the flow regime management, controlled by the operation of dozens of infiltration ponds and hundreds of surrounding recovery wells (RW) $[9,13,14,18]$. The recovered effluents after SAT are characterized by excellent quality for most of the measured parameters, and are significantly better than any other treated wastewater in Israel. According to the Israeli health regulations, the recovered Shafdan water (after SAT) is suitable for unrestricted irrigation of any crop $[9,16,17]$. Nevertheless, a rise of manganese concentrations in recovery wells since 2001 needs to be coped with [12].

To maintain the necessary separation between the Shafdan basins and the regional aquifer, and to avoid any breakout and contamination of fresh water wells by effluents, a proper hydrological management and an extensive monitoring system are required. The traditional and simplest way to track the spatial extension of the recharged effluent is to measure the concentrations of conservative tracers such as chloride in observation and recovery wells. In places where the difference between the pristine aquifer water $(50-150 \mathrm{mg}-\mathrm{Cl} / \mathrm{L})$ and the reclaimed water $(230-280 \mathrm{mg}-\mathrm{Cl} / \mathrm{L})$ is large enough, the chloride concentration is a suitable tool for tracing the effluent front in the aquifer and for estimating mixing ratios (MR) of effluent and freshwater. However, down-stream, where the effluents are diluted to less than $30 \%$ and the chloride concentration decreases, chloride can no longer be used as a reliable tracer [19-21]. Moreover, the chloride tracer has very limited use in specific areas that are located east of the Shafdan basins and are characterized by high salinity, in some cases higher than $300 \mathrm{mg}-\mathrm{Cl} / \mathrm{L}$, unrelated to the Shafdan recharged effluents [21]. In these cases, state-of-the-art geochemical and environmental tools are needed.

A new tracer that was discovered in the past few years takes advantage of the inert and conservative behavior of carbamazepine (CBZ), an antiepileptic drug which is present in the sewage 
as a micro-pollutant and is being recharged to the aquifer with the effluents. Previous studies proved the CBZ to be a useful tracer in the Shafdan system, especially down-stream where the effluents are diluted. It was shown that in these areas CBZ can be used for MR calculations of less than 5\% [18-23]. However, CBZ is limited to less diluted areas (MR > 80\%) and for prediction purposes, due to its unstable concentrations in the recharged effluents [21].

The present research hypothesized that the massive amounts of desalinated water added each year to the National Water Carrier should affect the supplied water isotopic composition, as well as the isotopic composition of the associated effluents treated by the Shafdan plant. The objectives of this study were to examine the applicability of the water isotopes ${ }^{18} \mathrm{O}$ and ${ }^{2} \mathrm{H}$ as a quantitative tool: (1) for tracing the spatial distribution of the recharged effluents in the Shafdan basins; and (2) for examination of the relationship between different water sources in the water-sewage-effluent system, that is, between the different water sources in the Israeli National Water Carrier, between the NWC and the Shafdan plant, and between the Shafdan plant and the SAT recovery wells.

\section{Materials and Methods}

\subsection{Sampling Program}

In order to verify the research hypothesis, an extensive survey was conducted, including sampling and analysis of water collected from recovery wells, from pipe connections of the NWC and from desalination plants. The main research took place in the area of the Soreq recharge basin, located at the northern part of the Shafdan plant. The aquifer in this area is subdivided into four sub-aquifers, A to $C$ (Figure 1). The main SAT activity, as well as the freshwater pumping, takes place in sub-aquifer B. In some places, the recharged water reaches also lower unit (sub-aquifers C). Some of the recovery wells penetrate several sub-aquifers and hence technically connect and exploit all of them.

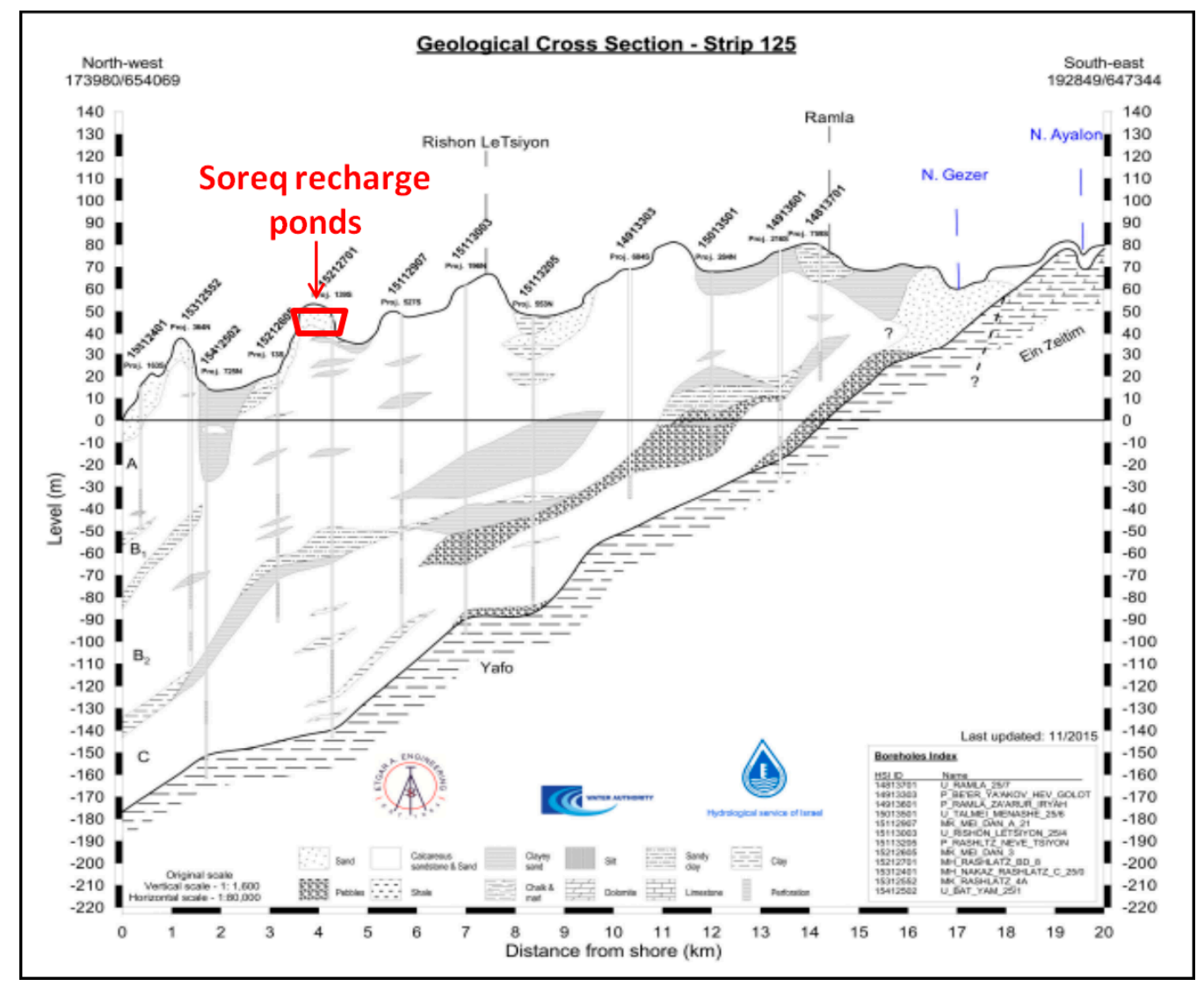

Figure 1. Cross section of the Coastal Aquifer and the area of the Soreq recharge basin (after [24]). 
Two sampling campaigns were conducted during the years 2010-2011 and 2014. The first campaign (2010-2011) was part of a France-Israeli bilateral research program, and included the examination of various isotopes and chemical compounds as a potential tracer for the Shafdan system $[25,26]$. The second campaign was conducted by Mekorot in order to validate the conclusions and the predictions of the first campaign. In each campaign, we sampled 17 to 21 recovery and monitoring wells, most of them 2-3 times (Figure 2). The sampled wells were carefully chosen to be located at various distances from the recharge ponds, and yet to be as similar as possible from the technical and hydro-geological aspects. A limited sampling campaign that included only the Shafdan effluents and 3 observation wells was conducted during winter 2013.

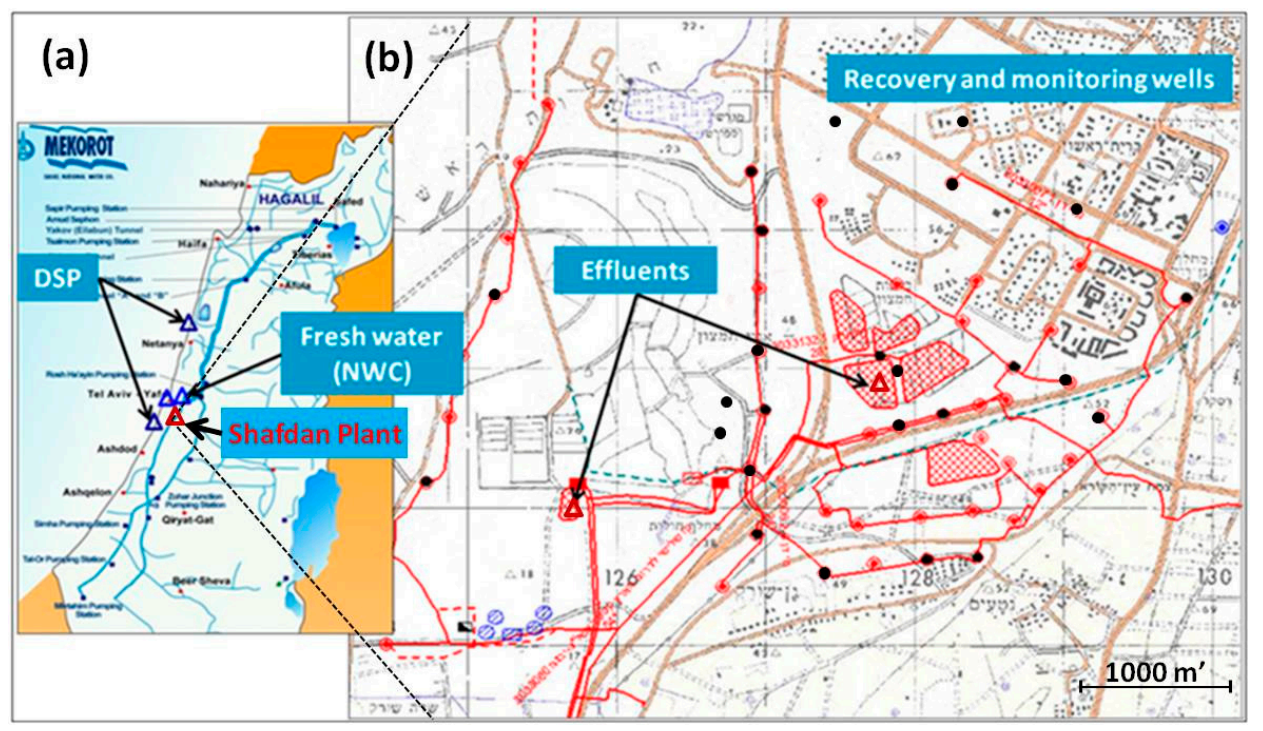

Figure 2. Experiment setup and the sampling program implemented in the study: (a) Schematic layout of the Israeli National Water Carrier with the locations of Hadera and Palmahim desalination plants (DSPs) and the Shafdan plant. Blue triangles represent the freshwater sampling points; (b) Enlarged map of the Shafdan area and the Soreq recharge basin. Red triangles represent effluents sampling points. Black dots represent recovery and observation wells that were sampled.

Table 1. General description of the sub-experiments conducted during the campaigns.

\begin{tabular}{lll}
\hline \multicolumn{1}{c}{ Examined Effect } & Campaign & \multicolumn{1}{c}{ Setup and Remarks } \\
\hline $\begin{array}{l}\text { Seasonal effects on the isotopic } \\
\text { composition of the recovered water } \\
\text { (after SAT) }\end{array}$ & & The first sampling campaign was divided into \\
& 2010-2011 parts: September 2010 (summer) and \\
& & February 2011 (winter). The two sub-campaigns \\
& & were conducted at the same wells or at \\
hydro-geologically equivalent wells.
\end{tabular}

(1) By simultaneous sampling from PS-6 (MTBE outlet) and from the recharge pond on 14 September 2010. Effluent sampling of the

Evaporation effects on the isotopic composition of the recharged effluents, during the recharge period

2010-2011

(2) By continuous sampling of the recharge pond
B during flooding on 19 September 2010 (beginning of flooding) and on 20 September 2010 (end of flooding).

(1) On 21 February 2011 and on 7 February 2013 effluents were sampled from the Shafdan during a period when no water was supplied

The effect of the Sea of Galilee and the desalinated water on the isotopic composition of the Shafdan effluents (see Section 3.3)
2010-2011, 2013 and 2014 from the lake to the NWC.

(2) On 25 February 2014 effluents were sampled from the Shafdan during a period when no water was supplied from the Hadera DSP and from the SOG to the NWC. 
Each campaign included sampling of secondary effluents from the outlet of the MBTP (PS-6) and from recharge ponds. Samples were also taken from two desalination plants (Palmahim and Hadera) and from specific points along the National Water Carrier, in order to represent the isotopic composition of the Dan Region's supplied freshwater (Figure 2). Each campaign also included specific sampling programs (sub-experiments) to evaluate the contributions of individual sources and the effects of secondary processes such as evaporation or seasonal variations, as listed in Table 1.

\subsection{Analytical Procedures}

Chemical analyses included measurement of salinity $(\mathrm{Cl}, \mathrm{EC})$ in all samples. In part of the samples, mainly during the first campaign, major ions $\left(\mathrm{Ca}, \mathrm{Mg}, \mathrm{Na}, \mathrm{K}, \mathrm{HCO}_{3}, \mathrm{SO}_{4}\right.$, and $\left.\mathrm{B}\right)$, nitrogen species $\left(\mathrm{NO}_{3}\right.$, $\mathrm{NH}_{4}$, and $\mathrm{NO}_{2}$ ), Redox parameters (DO, ORP, $\mathrm{Mn}$, and $\mathrm{Fe}$ ) and other parameters ( $\mathrm{pH}$, temperature, DOC, alkalinity, UV and metal concentrations) were also measured. This was done for quality control and comparison purposes, and is not discussed further in this paper. Analyses were conducted by the central laboratory of Mekorot using standard methods.

Potential tracers for mixing ratio (MR) calculations, including $\mathrm{Cl}, \mathrm{CBZ}$ and the stable isotopes of water molecule $\left({ }^{18} \mathrm{O}\right.$ and $\left.{ }^{2} \mathrm{H}\right)$, were measured at all wells. $\mathrm{CBZ}$ concentrations were measured in the central laboratory of the Israeli Water Authority. Measurements were done using liquid chromatograph equipped with tandem triple quadruple mass spectrometer LC/MS/MS according to the EPA method 1694, which enable limit of quantification (LOQ) of $0.1 \mathrm{ng} / \mathrm{L}$ [20]. The oxygen and hydrogen isotopes (expressed as $\delta^{18} \mathrm{O}$ and $\delta^{2} \mathrm{H}$ values in \%o vs. the VSMOW standard) were measured by two separated labs. Samples from the first campaign (2010-2011) were analyzed by the BRGM isotope laboratory on a Finnigan MAT 252 mass spectrometer following the gas-water equilibration technique with $\mathrm{CO}_{2}$ for oxygen isotopes [27] and with $\mathrm{H}_{2}$ for hydrogen isotopes [28]. Analytical uncertainty, based on replicate analyses of international and laboratory standards, are $\pm 0.8 \%$ o for $\delta^{2} \mathrm{H}$ and $\pm 0.1 \%$ o for $\delta^{18} \mathrm{O}$. Water and effluent samples from the second campaign (2014 and 2013) were analyzed by the IT $^{2}$ laboratory (Waterloo, ON, Canada) on CRDS, Model L1102-i (Piccaro, Santa Clara, CA, USA) for both oxygen and hydrogen isotopes. The instrument was configured with a unique vaporization module that converts the liquid water sample to the vapor phase in a flash process at $140^{\circ} \mathrm{C}$. The vapor was then delivered into the CRDS cavity for analysis. This process avoided any possible fractionation processes that may have occurred with other liquid/vapor transitions such as nebulizers. Typical precision for $\delta^{18} \mathrm{O}$ and $\delta^{2} \mathrm{H}$ are $\pm 0.1 \%$ and $\pm 0.6 \%$, respectively. All results were corrected and reported against the Vienna Standard Mean Ocean Water (VSMOW). All in-house standards were calibrated every six months by VSMOW, GISP and SLAP (The IAEA international standards).

All samples were analyzed in duplicates at both laboratories, with internal hidden standards for control.

\section{Results and Discussion}

\subsection{Isotopic Composition of the Shafdan System}

The results for the isotopic composition and concentrations of $\mathrm{Cl}$ and $\mathrm{CBZ}$ are given in Table 2. A typical correlation diagram of $\delta^{2} \mathrm{H}$ vs. $\delta^{18} \mathrm{O}$ for the Shafdan system (Figure 3a) and for the Israeli water system sources (Figure $3 b$ ) is given in Figure 3.

Examination of seasonal effects: Samples from recovery wells were taken during summer 2010 and winter 2011 (Table 1). No significant differences were found between these two sub-campaigns for $\mathrm{Cl}$ concentrations and for stable water isotope compositions. Thus, it can be concluded that there is no significant seasonal effect on the aquifer, and that the two sub-campaigns of 2010-2011 can be considered as one for further discussion. Seasonal effects on various chemical components in the Shafdan aquifer were examined in previous works (e.g., [16]) but never found. The reason for this is probably the moderating influence of the mixing in the aquifer on surface fluctuations and surface processes. 
Table 2. Cl, CBZ and isotopic compositions of freshwater, effluent and recovered effluents in the study.

\begin{tabular}{|c|c|c|c|c|c|c|c|c|}
\hline Location & Location Type & Water Type & Sampling Date & $\mathrm{Cl}(\mathrm{mg} / \mathrm{L})$ & $\mathrm{CBZ}(\mathrm{ng} / \mathrm{L})$ & $\delta^{2} \mathrm{H} \%$ vs. SMOW & $\mathcal{\delta}^{18} \mathrm{O} \%$ ov. SMOW & Notes \\
\hline DSP-Hadera & Desalination plant & Freshwater & $23 / 02 / 2011$ & 14 & $\mathrm{NM}^{1}$ & 10.0 & 1.5 & \\
\hline DSP-Palmahim & Desalination plant & Freshwater & $22 / 02 / 2011$ & 63 & NM & 9.7 & 1.5 & \\
\hline SYS-Lincoln & Local water system & Freshwater & $23 / 02 / 2011$ & 39 & NM & 1.7 & -0.1 & \\
\hline SYS-Bar Ilan & Main water system & Freshwater & $23 / 02 / 2011$ & 41 & NM & -1.8 & -0.8 & \\
\hline PS-6 & Plant outflow & Effluents & $14 / 09 / 2010$ & 260 & NM & -4.1 & -1.4 & Samples were taken from PS- 6 and from the \\
\hline Soreq-1: 103/2 & Recharged pond & Effluents & $14 / 09 / 2010$ & 260 & NM & -4.2 & -1.4 & recharge pond to study the effect of evaporation \\
\hline PS-6 & Plant outflow & Effluents & $21 / 02 / 2011$ & 223 & 837 & -8.2 & -2.0 & Sea of Galilee (SOG) is off \\
\hline PS-6 & Plant outflow & Effluents & $07 / 02 / 2013$ & NM & NM & -2.1 & -1.6 & SOG is off \\
\hline PS-6 & Plant outflow & Effluents & $25 / 02 / 2014$ & NM & NM & -5.6 & -2.4 & SOG and Hadera DSP are off \\
\hline PS-6 & Plant outflow & Effluents & $25 / 03 / 2014$ & 209 & 1132 & -0.3 & -1.2 & \\
\hline Yavne-2: 5102 & Recharged pond & Effluents & $19 / 09 / 2010$ & 280 & NM & -5.9 & -1.7 & Continuous flooding to study the effect \\
\hline Yavne-2: 5102 & Recharged pond & Effluents & $20 / 09 / 2010$ & 276 & NM & -5.5 & -1.5 & of evaporation \\
\hline Shoreg T-1 & Observation Well & SAT & $08 / 05 / 2014$ & 134 & 2 & -20.4 & -4.7 & \\
\hline Shoreq T-2 & Observation Well & SAT & $08 / 05 / 2014$ & 128 & 36 & -10.8 & -2.8 & \\
\hline Shoreq T-27/1 & Observation Well & SAT & $10 / 07 / 2014$ & 272 & 684 & -9.1 & -2.3 & \\
\hline Shoreq T-5 & Observation Well & SAT & $10 / 07 / 2014$ & 89 & 74 & -12.7 & -3.2 & \\
\hline Shoreq T-61 & Observation Well & SAT & $26 / 03 / 2014$ & 268 & 1010 & -2.7 & -1.1 & \\
\hline Shoreq T-62/1 & Observation Well & SAT & $26 / 03 / 2014$ & 201 & 1166 & -0.5 & -0.9 & \\
\hline Shoreq T-71d & Observation Well & SAT & $26 / 03 / 2014$ & 88 & 20 & -15.0 & -3.8 & \\
\hline Shoreq T-71s & Observation Well & SAT & $26 / 03 / 2014$ & 197 & 188 & -7.5 & -2.6 & \\
\hline Soreq $\mathrm{t}-1 \mathrm{a}$ & Observation Well & SAT & $30 / 04 / 2013$ & NM & NM & -19.4 & -5.0 & \\
\hline Soreq $\mathrm{t}-2 \mathrm{a}$ & Observation Well & SAT & $30 / 04 / 2013$ & NM & NM & -20.0 & -5.0 & \\
\hline Soreq $\mathrm{t}-3$ & Observation Well & SAT & $30 / 04 / 2013$ & NM & NM & -20.3 & -5.0 & \\
\hline Soreq T-61 & Observation Well & SAT & $21 / 02 / 2011$ & 250 & 1030 & -7.3 & -1.8 & \\
\hline Dan 1 & Recovery Well & SAT & $08 / 05 / 2014$ & 290 & 1900 & -10.1 & -3.1 & \\
\hline Dan 14a & Recovery Well & SAT & $08 / 05 / 2014$ & 163 & 446 & -12.2 & -3.5 & \\
\hline Dan 21a & Recovery Well & SAT & $25 / 03 / 2014$ & 153 & 380 & -13.5 & -3.6 & \\
\hline Dan 25 & Recovery Well & SAT & $25 / 03 / 2014$ & 248 & 1096 & -11.1 & -3.1 & \\
\hline Dan 2a & Recovery Well & SAT & $25 / 03 / 2014$ & 152 & 482 & -12.3 & -3.4 & \\
\hline Dan 33 & Recovery Well & SAT & $25 / 03 / 2014$ & 258 & 1158 & -2.8 & -1.4 & \\
\hline Dan 5 & Recovery Well & SAT & $25 / 03 / 2014$ & 264 & 1236 & -5.2 & -1.9 & \\
\hline Dan 6 & Recovery Well & SAT & $25 / 03 / 2014$ & 260 & 1236 & -4.8 & -2.0 & \\
\hline Dan 7 & Recovery Well & SAT & $25 / 03 / 2014$ & 209 & 650 & -10.4 & -2.8 & \\
\hline Dan 8 & Recovery Well & SAT & $25 / 03 / 2014$ & 246 & 860 & -7.7 & -2.3 & \\
\hline Dan-16a & Recovery Well & SAT & $21 / 02 / 2011$ & 277 & 870 & -12.2 & -2.7 & \\
\hline Dan-17a & Recovery Well & SAT & $14 / 09 / 2010$ & 240 & NM & -14.1 & -3.4 & \\
\hline Dan-17a & Recovery Well & SAT & $21 / 02 / 2011$ & 246 & 1296 & -14.1 & -3.1 & \\
\hline Dan-24 & Recovery Well & SAT & $14 / 09 / 2010$ & 289 & NM & -12.3 & -3.0 & \\
\hline Dan-24 & Recovery Well & SAT & $21 / 02 / 2011$ & 291 & 1337 & -12.6 & -2.8 & \\
\hline Dan-2a & Recovery Well & SAT & $14 / 09 / 2010$ & 164 & NM & -15.4 & -3.6 & \\
\hline Dan-2a & Recovery Well & SAT & $21 / 02 / 2011$ & 160 & 299 & -15.2 & -3.5 & \\
\hline Dan-32 & Recovery Well & SAT & $14 / 09 / 2010$ & 280 & NM & -10.1 & -2.6 & \\
\hline Dan-32 & Recovery Well & SAT & $21 / 02 / 2011$ & 278 & 1174 & -10.2 & -2.3 & \\
\hline
\end{tabular}


Table 2. Cont.

\begin{tabular}{llcccccc}
\hline \multicolumn{1}{c}{ Location } & Location Type & Water Type & Sampling Date & Cl (mg/L) & CBZ (ng/L) & $\mathcal{\delta}^{\mathbf{2}} \mathbf{H}$ \%o vs. SMOW & $\mathcal{\delta}^{\mathbf{1 8}} \mathbf{O}_{\text {\%o vs. SMOW }}$ \\
\hline Dan-5 & Recovery Well & SAT & $21 / 02 / 2011$ & 284 & 1061 & -12.5 & -2.9 \\
Dan-6 & Recovery Well & SAT & $14 / 09 / 2010$ & 279 & NM & -12.9 & -3.0 \\
Dan-6 & Recovery Well & SAT & $21 / 2 / 2011$ & 277 & 1210 & -12.2 & -2.8 \\
Dan-7 & Recovery Well & SAT & $21 / 202 / 2011$ & 228 & 1000 & -13.3 & -3.2 \\
NH Rishon 10 & Recovery Well & SAT & $25 / 203 / 2014$ & 66 & 353 & -16.0 & -4.1 \\
NH Rishon 7 & Recovery Well & SAT & $25 / 3 / 2014$ & 86 & 44 & -15.4 & -3.7 \\
NH Rishon-10 & Recovery Well & SAT & $21 / 02 / 2011$ & 62 & 314 & -21.3 & -4.6 \\
Rishon 5 & Recovery Well & SAT & $25 / 03 / 2014$ & 86 & 140 & -17.4 & -4.1 \\
Rishon-5 & Recovery Well & SAT & $14 / 09 / 2010$ & 123 & NM & -16.4 & -3.8 \\
Rishon-5 & Recovery Well & SAT & $21 / 02 / 2011$ & 114 & 72 & -17.8 & -3.8 \\
\hline \multicolumn{7}{c}{ Note: ${ }^{1}$ NM: not measured. }
\end{tabular}

Table 3. $\mathrm{Cl}, \mathrm{CBZ}$ and isotopic composition average values of different types of water sources.

\begin{tabular}{|c|c|c|c|c|c|c|c|c|}
\hline \multirow{2}{*}{ Water Source } & \multicolumn{2}{|c|}{$\mathrm{Cl}(\mathrm{mg} / \mathrm{L})$} & \multicolumn{2}{|c|}{ CBZ (ng/L) } & \multicolumn{2}{|c|}{$\delta^{2} \mathbf{H} \%$ vs. SMOW } & \multicolumn{2}{|c|}{$\delta^{18} \mathrm{O} \%$ vs. SMOW } \\
\hline & Average & Stdev (n) & Average & Stdev (n) & Average & Stdev (n) & Average & Stdev (n) \\
\hline Coastal Aquifer $(\mathrm{Cl}<200)$ & 101 & $54(27)$ & \multirow{3}{*}{$3^{1}$} & \multirow{3}{*}{-} & -18.6 & $2.53(27)$ & -4.62 & $0.33(27)$ \\
\hline Coastal Aquifer $(\mathrm{Cl}>200)$ & 458 & $240(33)$ & & & -17.8 & $2.19(31)$ & -4.09 & $0.37(33)$ \\
\hline Coastal Aquifer (general) & 297 & $250(58)$ & & & -18.2 & $2.42(58)$ & -4.33 & $0.42(60)$ \\
\hline Mountain aquifer & $198^{2}$ & $187(36)$ & NM & - & -22.1 & $2.80(42)$ & -5.36 & $0.37(43)$ \\
\hline Sea of Galilee & 261 & 18 & NM & - & 0.88 & $2.97(13)$ & -0.37 & $0.44(13)$ \\
\hline Mediteranean Sea ${ }^{3}$ & 38 & $35(2)$ & NM & - & 8.90 & $1.74(13)$ & 1.74 & $0.19(13)$ \\
\hline Shafdan effluents, 2010-2011 & 265 & $28(103)$ & \multirow[b]{2}{*}{1071} & \multirow{2}{*}{$230(8)$} & -4.93 & $0.89(4)$ & -1.52 & $0.10(4)$ \\
\hline Shafdan effluents, 2014 & 218 & $27(53)$ & & & -1.20 & $1.30(2)$ & -1.39 & $0.23(2)$ \\
\hline
\end{tabular}

Notes: ${ }^{1} \mathrm{CBZ}$ in pristine water: according to Gasser et al. [20]; ${ }^{2}$ For pumping wells with salinity of $\mathrm{Cl}<1000 ;{ }^{3} \mathrm{Cl}$ : for desalinated water only; Isotopes: desalinated and sea water. 
Examination of evaporation effects in the recharge ponds: Various samples taken from the recharge ponds, during different hours along the recharge process, were compared (Table 1). No significant differences in the $\delta^{2} \mathrm{H}$ and $\delta^{18} \mathrm{O}$ values were found. Thus, it can be concluded that the effect of evaporation during the recharge process on the fractionation of the stable water isotopes is negligible for the Shafdan case, and that mixing and dilution processes dictate the isotopic compositions in the aquifer.

A scattered plot of $\delta^{2} \mathrm{H}$ vs. $\delta^{18} \mathrm{O}$, based on the results of the isotopes compositions in the secondary effluents and in the SAT recovery wells, show a significant linear correlation with a slope of 4.9 and $R^{2}=0.93$ (Figure 3a). This slope is significantly lower than the GMWL line slope of 8 . In addition, Figure 3a clearly shows that the Shafdan system is dominated by two discrete end-members: the secondary recharged effluents on the heavier end, and the pristine aquifer water on the lighter end.

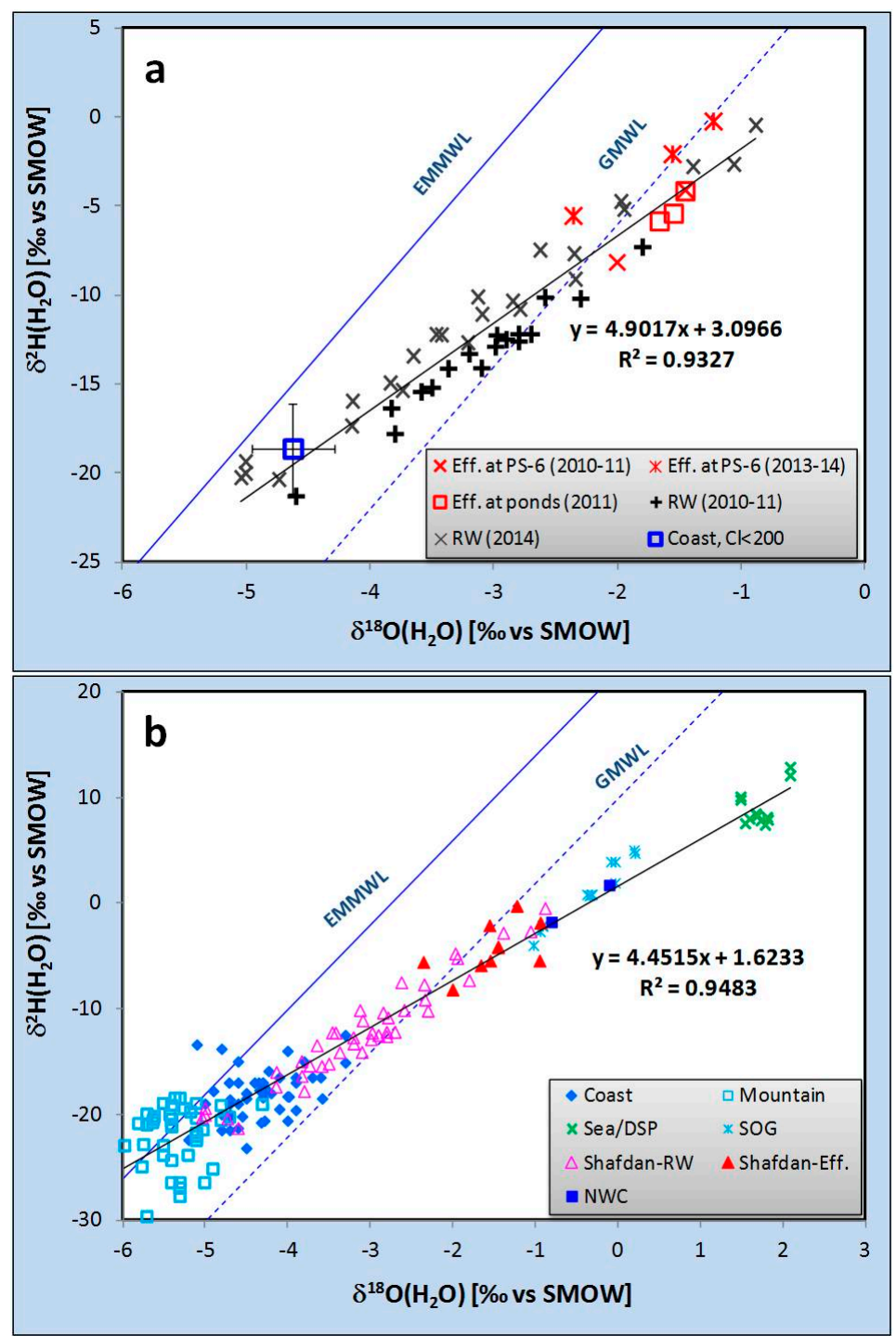

Figure 3. Water molecule isotopic compositions: (a) the Shafdan system, including the recharged effluents (PS-6 or at the ponds) and the recovery wells (RW); and (b) the freshwater sources, in the National Water Carrier (NWC) and in the Shafdan system. Isotope data for the Coastal Aquifer, Mountain Aquifer, Mediterranean Sea, desalinated water (DSP), and for the Sea of Galilee (SOG) were taken from previous works [3,5,8,29-35]. 
The secondary effluents compose the heavier end-member, with $\delta^{18} \mathrm{O}$ of $-1.5 \pm 0.1$ and $\delta^{2} \mathrm{H}$ of $-4.9 \pm 0.9$ for $2010-2011$ campaign, and $\delta^{18} \mathrm{O}$ of $-1.4 \pm 0.2$ and $\delta^{2} \mathrm{H}$ of $-1.2 \pm 1.3$ for 2014 campaign (Table 3). The variations for these average values are due to changes in dilution ratio between water from different sources in the NWC (Table 1). For example, relatively depleted $\delta^{2} \mathrm{H}$ and $\delta^{18} \mathrm{O}$ values were measured in the effluent on 21 February 2011 and on 25 February 2013. These values can be explained by the shutoff of the SOG and the Hadera desalination plant during these periods (Tables 1 and 2), accompanied by increasing contributions from the Mountain Aquifer wells in order to compensate for water shortage in the NWC. More details regarding the variations in water amounts between different water sources are given in Table 4 and in Section 3.3 below.

The Coastal Aquifer pristine water compose the lighter end-member, with $\delta^{18} \mathrm{O}$ of $-4.6 \pm 0.3$ and $\delta^{2} \mathrm{H}$ of $-18.6 \pm 2.5$ in water of salinity smaller than $200 \mathrm{mg}-\mathrm{Cl} / \mathrm{L}$, which is typical of the Shafdan area (Table 3).

All the isotope composition values of the recovery and observation wells were linearly scattered between the effluent and the Coastal Aquifer end-members (Figure 3a). Assuming no fractionation processes take place during the SAT process, and considering the conservative behavior of the water isotopes, this pattern represents a mixing line between the recharged effluents and the native water, where the isotope composition in each well is affected only by mixing of these two end-members. Accordingly, a mixing ratio (MR) in each well is directly correlated to its isotope composition, and can be calculated as follows:

$$
M R(\%)=\frac{\delta-\delta_{N W}}{\delta_{e f f}-\delta_{N W}} * 100
$$

where $\delta$ represents the measured $\delta^{18} \mathrm{O}$ or $\delta^{2} \mathrm{H}$ in the well, $\delta_{\mathrm{NW}}$ represents the $\delta^{18} \mathrm{O}$ or $\delta^{2} \mathrm{H}$ of the pristine water (aquifer), and $\delta_{\text {eff }}$ represents the $\delta^{18} \mathrm{O}$ or $\delta^{2} \mathrm{H}$ of the Shafdan effluents. It is important to note that $\delta$ can be replaced by concentration values of any conservative tracing marker that is valid for the Shafdan system, such as $\mathrm{Cl}$ or CBZ.

\subsection{Isotopic Composition of the Main Water Sources and of the National Water Carrier}

Expanding the $\delta^{2} \mathrm{H}$ vs. $\delta^{18} \mathrm{O}$ diagram of Figure $3 \mathrm{a}$ to include all the samples that were taken in this and other surveys and studies, reveals an interesting result. It clearly shows that all the sampled freshwater sources of Israel, and all the samples that were taken from different points along the NWC, are scattered along a regression line similar to the Shafdan system, with a slope of 4.5 and $R^{2}$ of 0.95 (Figure 3b). This time the end-members are composed of the Mediterranean Sea water, either preor post-desalination, and from the Mountain Aquifer water. Isotope data for the Coastal Aquifer, Mountain Aquifer, Mediterranean Sea, desalinated water and for the SOG were taken from previous studies [3,5,8,29-35].

The heavy end-member is composed of the Mediterranean Sea water, with $\delta^{18} \mathrm{O}$ of $1.7 \pm 0.2$ and $\delta^{2} \mathrm{H}$ of $8.9 \pm 1.7$. Previous studies showed that water isotopes are not subjected to fractionation during the various treatments stages involved in the desalination processes [8]. The Sea of Galilee water are also characterized by a relatively heavy signature, with $\delta^{18} \mathrm{O}$ of $-0.4 \pm 0.4$ and $\delta^{2} \mathrm{H}$ of $0.9 \pm 3.0$. On the other end, we can find the Mountain Aquifer water that represent the lighter end member, with $\delta^{18} \mathrm{O}$ of $-5.4 \pm 0.4$ and $\delta^{2} \mathrm{H}$ of $-22.1 \pm 2.8$, just slightly lower than the Coastal Aquifer water with $\delta^{18} \mathrm{O}=-4.3 \pm 0.4$ and $\delta^{2} \mathrm{H}=-18 \pm 2.4$ for all salinity range (Table 3 ).

The slope of the regression line is 4.5 , a little smaller but not significantly different from the slope of the Shafdan system in Figure 3a. Some studies have shown that slopes smaller than 8 , which characterize the GMWL and EMMWL lines, are typical for mixing and evaporating systems (e.g., [29,36-38]). In a specific study, a slope of 4.3 was measured for water systems under controlled evaporating conditions [36]. Thus, the slope range of 4.5 to 4.9 that was calculated in this study suggests that evaporation had significant effect on the isotope composition of each one of the NWC water sources. This may not be surprising given the fact that at least three out of the four main freshwater sources are subjected to evaporation under similar climatic conditions. This includes the 
Mediterranean Sea and the derived desalinated water that is pumped relatively close to the shore line, the SOG open lake, and the recharged water of the Coastal Aquifer [32]. A small fraction of the Mountain Aquifer recharge water is also subjected to evaporation when rain storms occur under warm climate conditions [37], but even without this component, the isotopic composition of this source does not interfere with the linear pattern.

\subsection{Mixing Ratios in the National Water Carrier and in the Shafdan Plant}

Mixing ratios between different water sources can be calculated based on the strong linearity between the four main freshwater sources (Figure 3b). The linear correlation enables us to run simple dilution (mixing) calculations between the different water sources in the NWC and in the Shafdan plant. That is, calculating the isotopic composition $\delta$ of a mixed system such as the NWC or the Shafdan effluents according to the volume ratio $\left(\mathrm{f}_{\mathrm{i}}\right)$ and the isotopic composition $\left(\delta_{\mathrm{i}}\right)$ of each source (Equation (2)):

$$
\delta=\sum_{i=1}^{n} \delta_{i} \cdot f_{i}
$$

where $\delta$ represents the calculated $\delta^{18} \mathrm{O}$ or $\delta^{2} \mathrm{H}$ value (\%o) of the mixed system, and $\delta_{\mathrm{i}}$ represents the measured $\delta^{18} \mathrm{O}$ or $\delta^{2} \mathrm{H}$ value (\%o) of the fresh water source (Coastal Aquifer, Mountain Aquifers, SOG or desalinated water). Assumptions for using the mixing model to calculate the isotope composition of the NWC includes no fractionation and instantaneous, homogenous, mixing between the water sources in the line. Additional assumptions for calculating the isotope composition in the Shafdan effluents includes no fractionation and evaporation throughout the usage of the water and the treatment process; no external, uncounted water source; and instantaneous, homogenous, mixing between NWC and private wells in the local systems, and between different sewage sources from the different municipalities in the Shafdan MBTP.

Freshwater quantities for each main source for the calculation of the isotope composition in the National Water Carrier were taken from the Mekorot daily database. Mixing calculation for the NWC was conducted by a water supply operative program (code) that was developed and is operated by Mekorot, as part of the NWC operating system. Freshwater quantities for private wells (Coastal and Mountain aquifers) owned by the municipalities were taken from the Water Authority's monthly database. In order to calculate the dilution ratios between different types of water sources in the Shafdan, we assumed that the municipal consumption is first provided by the private wells (from water cost considerations), and the residual is purchased from the NWC. Thus, the isotope composition of the Shafdan effluents $\left(\delta_{\text {shafdan }}\right)$ was calculated from the volume ratios between the private wells and the NWC ( $f_{\mathrm{PW}}$ and $\mathrm{f}_{\mathrm{NWC}}$, respectively), and from the isotopic compositions of these two sources ( $\delta_{\mathrm{PW}}$ and $\delta_{\mathrm{NWC}}$, respectively), as described in Equation (3).

$$
\delta_{\text {shafdan }}=f_{P W} \cdot \delta_{P W}+f_{N W C} \cdot \delta_{N W C}
$$

Purchased volumes of NWC water by the municipalities were obtained from the accounting system of Mekorot (on a monthly base). The isotopic composition of each water source that was used for the mixing calculation is detailed in Table 3. Water volumes data for the calculations are given in Table 4.

Figure 4 presents the correlations between measured and calculated $\delta^{18} \mathrm{O}$ and $\delta^{2} \mathrm{H}$ values in the National Water Carrier and in the Shafdan systems. The Shafdan plant represents the mixing of different water from different sources along the water system chain, from freshwater down to sewage and treated effluent. Effluent samples from the Shafdan were taken during specific dates that represent different operation regimes of the NWC, as detailed in Table 1. Mixing calculations according to Equations (2) and (3) were conducted for these dates given the assumptions of no fractionations and no external (uncounted sources) effects on the isotope composition. Most of the calculated isotope compositions agree fairly well with the observed values as can be seen in Figure 4. High deviations of 
up to $1.5 \%$ and $7.5 \%$ o for the $\delta^{18} \mathrm{O}$ and $\delta^{2} \mathrm{H}$, respectively, were found only in the first sample taken on 14 September 2010. This deviation can be explained by the difficulty to assess the effects of the desalinated water on the NWC when only Ashkelon and Palmahim (partially) plants were working. For the rest of the samples, the deviations varied between $0 \%$ and $0.7 \%$ for the $\delta^{18} \mathrm{O}$, and between $1 \%$ and $3.7 \%$ o for the $\delta^{2} \mathrm{H}$. In the winter season, some limited effect of uncounted drainage runoff during stormy days can also explain part of the deviations. Nevertheless, the good overall agreement between calculated and measured values indicates the conservative nature of $\mathrm{O}$ and $\mathrm{H}$ stable isotopes in the water-effluent system, and, consequently, the ability to reconstruct or to predict the isotope composition of the recharged effluents.

Table 4. Water volumes from the different freshwater sources that were used for the dilution (mixing) calculations.

\begin{tabular}{|c|c|c|c|c|c|c|}
\hline \multirow{2}{*}{ Water Source } & \multirow{2}{*}{ System } & \multicolumn{5}{|c|}{ Volumes (MCM/Day) at Sampling Date } \\
\hline & & 14 September 2010 & 21 February 2011 & 07 February 2013 & 25 February 2014 & 25 March 2014 \\
\hline Coastal Aquifer & & 0.247 & 0.074 & 0.046 & 0.048 & 0.077 \\
\hline Mountain Aquifer & & 0.650 & 0.367 & 0.112 & 0.253 & 0.183 \\
\hline Lake Kinneret (SOG) & & 0.472 & 0.000 & 0.000 & 0.000 & 0.000 \\
\hline Palmahim DSP & National Water & 0.108 & 0.089 & 0.178 & 0.165 & 0.169 \\
\hline Hadera DSP & Carrier (Mekorot) ${ }^{1}$ & 0.273 & 0.276 & 0.374 & 0.000 & 0.316 \\
\hline Soreq DSP & & - & - & - & 0.010 & 0.313 \\
\hline Sum in NWC & & 1.75 & 0.81 & 0.71 & 0.48 & 1.06 \\
\hline $\begin{array}{l}\text { Purchased by } \\
\text { municipalities }\end{array}$ & & 0.31 & 0.25 & 0.27 & 0.27 & 0.30 \\
\hline Coastal aquifer & & 0.115 & 0.087 & 0.088 & 0.088 & 0.095 \\
\hline Mountain aquifer & $\begin{array}{c}\text { Private wells } \\
\text { (municipalities) }{ }^{2}\end{array}$ & 0.019 & 0.019 & 0.021 & 0.021 & 0.022 \\
\hline Sum & & 0.13 & 0.11 & 0.11 & 0.11 & 0.12 \\
\hline
\end{tabular}

Notes: ${ }^{1}$ Daily amounts; ${ }^{2}$ Estimated daily amounts, based on monthly data.
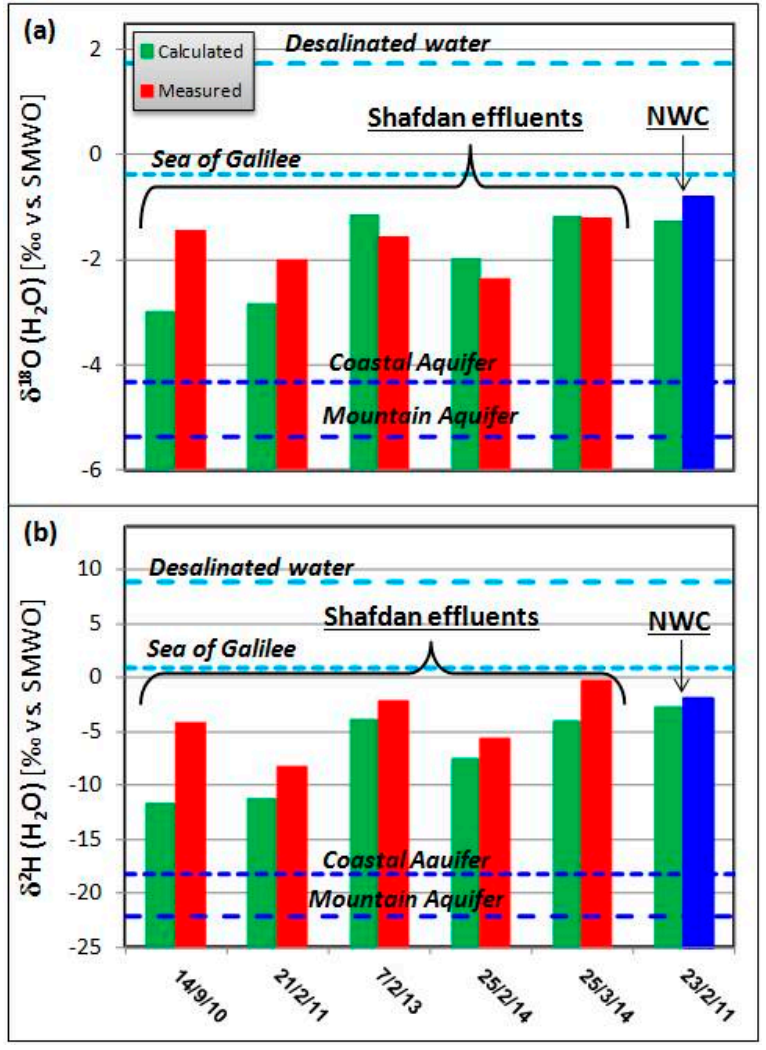

Figure 4. Fresh water mixing assessment in the NWC and in the Shafdan for: $\delta^{18} \mathrm{O}(\mathbf{a})$; and $\delta^{2} \mathrm{H}(\mathbf{b})$. The sampling point for the NWC is located at the entrance to Tel Aviv. Samples for the Shafdan effluents were taken at the outlet station (PS-6) that pumps the effluents to the recharge ponds. 


\subsection{Mixing Ratios in the Aquifer (SAT Basin)}

The isotopic composition of the Shafdan effluent is directly affected by the mixing of different amounts of water with different isotopic compositions in the Israeli National Water Carrier and in the municipal sewage systems. The most dramatic effect was due to the introduction of massive amounts of desalinated water during 2010 with the beginning of the operations of the Hadera plant (145 MCM/year), and the addition of the Soreq plant (150 MCM/year) in 2013. The introduction of the desalinated water with its relatively heavy isotopic signature induced a shift in the isotopic composition of the Shafdan effluents, and led to segregation from the Coastal Aquifer pristine water composition. The differences between these two end-members ("new" effluent and the Coastal Aquifer) made it practical to conduct reliable mixing ratio calculations using Equation (1).

Mixing ratio calculations for recovery and observation wells are presented in Figures 5 and 6 as a function of the distance of the wells from the recharge ponds. Calculations of MRs were done independently four times for each well, using its measured $\delta^{18} \mathrm{O}$ and $\delta^{2} \mathrm{H}$ values, $\mathrm{CBZ}$ and chloride concentrations. Figure 5 represents mixing ratio calculations for each parameter according to the 2010-2011 campaign results. Figure 6 represents the changes in the mixing ratio results between 2010-2011 and 2014, where MR is calculated from $\delta^{2} \mathrm{H}$ values and from CBZ concentrations.

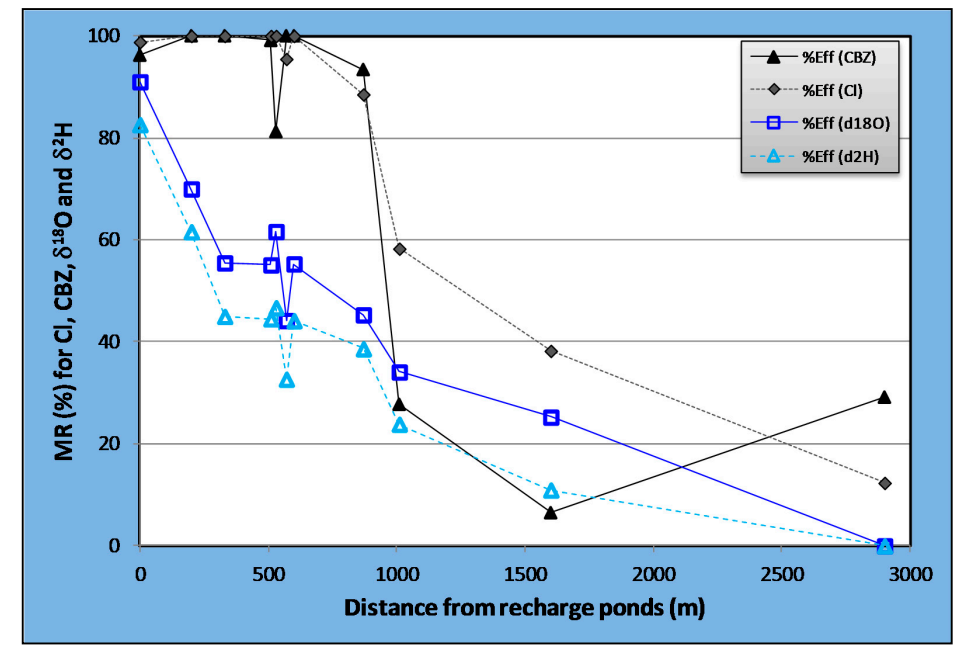

Figure 5. Mixing ratios (MR) in recovery and observation wells vs. distance from the recharge ponds. MRs were calculated from $\mathrm{Cl}, \mathrm{CBZ}, \delta^{18} \mathrm{O}$ and $\delta^{2} \mathrm{H}$ results of the 2010-2011 campaign.

Mixing ratio calculations for the 2010-2011 campaign showed significant differences between $\mathrm{CBZ}$ and $\mathrm{Cl}$ results compared to $\delta^{18} \mathrm{O}$ and $\delta^{2} \mathrm{H}$ results (Figure 5). $\mathrm{CBZ}$ and $\mathrm{Cl}$ concentrations led to higher MR values, which varied from $100 \%$ to $80 \%$ of effluents for wells in the range of 0 to $1000 \mathrm{~m}$ away from the recharge ponds, and from $60 \%$ to $5 \%$ for wells located 1000 to $3000 \mathrm{~m}$ from the ponds. Local differences between CBZ and $\mathrm{Cl}$ MRs are mainly due to inaccurate Cl-MR calculations under dilute (low MR) conditions. Mixing ratios based on $\delta^{18} \mathrm{O}$ and $\delta^{2} \mathrm{H}$ analyses yield smaller MR values, which varied between $20 \%$ and $90 \%$ of effluents for wells located 0 to $1000 \mathrm{~m}$ from the recharge ponds, and from $35 \%$ to $0 \%$ for wells located 1000 to $3000 \mathrm{~m}$ from the ponds. On average, mixing ratios calculations based on $\delta^{18} \mathrm{O}$ and $\delta^{2} \mathrm{H}$ values reached about $50 \%$ of the mixing ratios that were calculated from CBZ concentrations, which represent equilibrium with the SAT operation regime. Therefore, one can conclude replacement of about $50 \%$ of the previous isotopic signature with the "new" isotopic signature of the effluents, which occurred over one (since the operation of Hadera plant) to five (since the operation of Ashkelon plant) years.

As mentioned before in Section 2.1, the 2014 campaign was conducted in order to verify the conclusions from the 2010-2011 campaign. In particular, that the introduction of the desalinated water, via the National Water Carrier to the aquifer is expected to increase mixing ratio of "new" effluents in 
the recovery wells [25]. This conclusion is indeed confirmed as $\delta^{2} \mathrm{H}-\mathrm{MR}^{\prime} \mathrm{s}$ results increased from $\sim 50 \%$ to $\sim 75 \%$ relative to CBZ-MR's results in the main SAT-active area (100\% effluents based on CBZ) of the aquifer, as shown in Figure 6. Assuming negligible effect of the desalinated water until 2010 (due to weak connection of the Ashkelon plant to the Dan Region water system, and due to low contribution from the Palmahim plant until 2013), we conclude that the isotope signature of the desalinated water almost reached steady-state with the Shafdan SAT operation regime after about four years (since the operation of Hadera plant). This process of "replacing" the previous water body with the new effluents affected by the desalinated water is expected to continue in the next few years until equilibrium with the operation regime is reached. Accordingly, the stable water isotopes could be used as a reliable and accurate tracer to track the transport and spreading of the effluent in the aquifer.

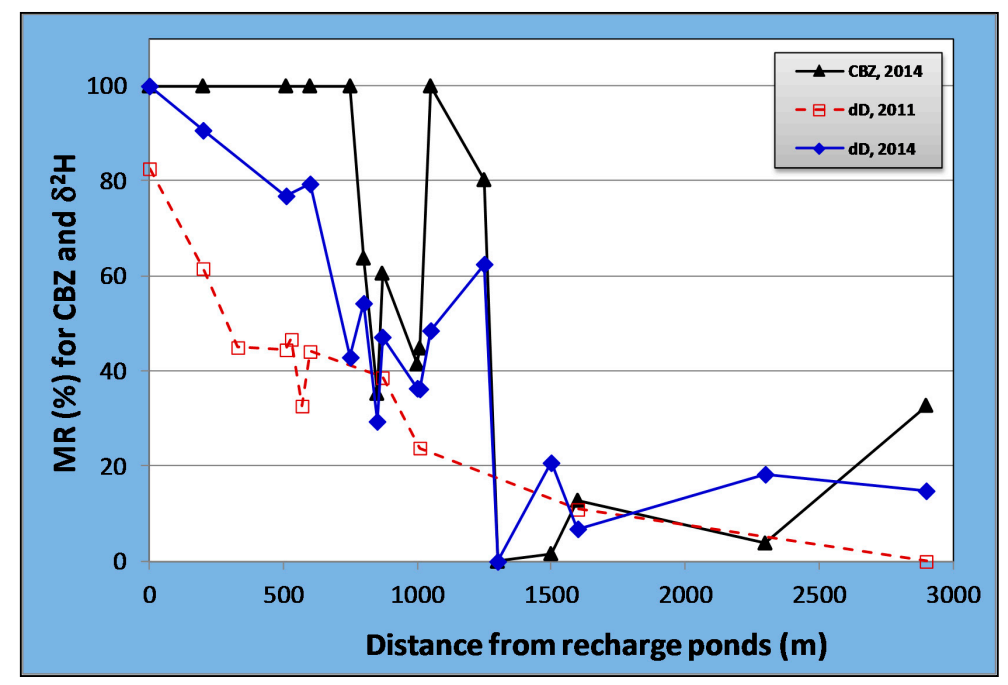

Figure 6. Mixing Ratios (MR) in recovery and observation wells vs. distance from the recharge ponds. MRs were calculated from CBZ results in the 2014 campaign (represent also the 2010-2011 campaign assuming steady-state conditions), and from $\delta^{2} \mathrm{H}$ in the 2010-2011 and 2014 campaigns (represent also MR- $\delta{ }^{18} \mathrm{O}$ results).

\section{Summary and Conclusions}

The present work examined the feasibility of using the stable water isotopes ${ }^{2} \mathrm{H}$ and ${ }^{18} \mathrm{O}$ as tracers for tracking different freshwater and effluent sources in the Israeli National Water Carrier (NWC), in the Dan Region sewage-effluent system (the Shafdan plant), and in the aquifer during the subsequent SAT process. Two sampling campaigns were conducted through 2010-2011 and 2014 in specific points along the NWC, in the Shafdan effluents, and in a set of recovery and observation wells. Each campaign included simultaneous measurements of the water isotopes, as well as carbamazepine (CBZ) and chloride concentrations $(\mathrm{Cl})$ as referent tracers for the Shafdan-SAT system.

The results of this work show, for the first time, the tremendous effect of the desalinated water on the isotopic composition of the mixed water in the NWC, in the Shafdan facility and in the SAT basins. This study also demonstrates for the first time on the linear isotopic composition relationship between the four main freshwater sources of Israel (and their mixed products), and the moderate slope regression line compared to the slopes of the meteoric water lines. These results enabled the use of the water isotopes as a conservative tracer throughout the completely manmade water cycle, starting from the freshwater sources, and all the way to the SAT system and the recovery wells.

The distinct difference in isotopic composition between the various freshwater sources, along with the data regarding volume ratios between these sources in the centralized water system, enable us to assess the isotopic composition of their mixed products in the NWC and in the Shafdan, based on simple dilution equations. The progressive enrichment of the Shafdan effluents in heavy isotopes, 
due to the massive amounts of desalinated water added to the system during the last decade, enables us to run quantitative mixing ratio calculations and to assess the spatial distribution of the effluents in the aquifer. In this work it was clearly shown that the isotopic composition of the recovery wells follow the same pattern of the $\mathrm{CBZ}$ and $\mathrm{Cl}$ concentrations; that is, reduction in calculated effluent rates with increasing distance from the recharge ponds. We could also demonstrate that the "new" effluents that are derived from desalinated water are now in the middle of a breakthrough process, replacing the "old" effluents in the aquifer.

The conclusions of this work are relevant and applicable for the Israeli water-sewage-effluent system, as well as for other places around the world. The dominance of the desalinated water in the NWC, together with the known amounts of water from other sources, assures stable and predictable isotopic trends in the Shafdan effluents and in the aquifer. The use of water isotopes for managing aquifer recharge (MAR) and for tracing the spreading of the recharged water in the aquifer can be applied worldwide. In places where desalinated or evaporated lake water bodies are recharged to the aquifers, this tool is potentially more accurate and reliable compared to traditional tracers such as $\mathrm{Cl}$ ions. It can also be applied for tracing mixing processes in water systems in places where two or more water sources are in use.

Additional study is still needed to achieve a better understanding of the nature and mechanism of the linear correlation between the main freshwater sources of the Israeli water system, and their mixing in the NWC and in the Shafdan. Further, routine sampling and measurements in the Shafdan are highly recommended in order to verify the prediction of further isotope enrichment, and in order to trace the effluent spreading in the aquifer.

Acknowledgments: This research was supported by Mekorot and BRGM research funds, and by the Israeli-France High Council for Scientific \& Technological Research within the Environment and Energy program. We wish to thank the Mekorot Shafdan team for their help and support in sampling and fieldwork, and also thank the Water Authority laboratory team for the CBZ analyses. We also wish to thank Dani Cohen (Mekorot) for his help in calculating mixing ratios in the NWC, Yoram Katz (Mekorot) for information regarding the flow model and retention time in the aquifer, and to Avihu Burg and Itai Gavrieli (Geological Survey Institute of Israel (GSI)) for their kind support throughout the study.

Author Contributions: Ido Negev and Joseph Guttman conceived and designed the experiments; Ido Negev performed the experiments, analyzed the data and established the conceptual model of mixing ratios in the water system; Wolfram Kloppmann provided isotope data from the BRGM isotope laboratory and contributed to the interpretation; Ido Negev wrote the paper.

Conflicts of Interest: The authors Ido Negev and Joseph Guttman are Mekorot employees, who manage and operate the National Water Carrier and the Shafdan plant. However, the subject of this research: "to search and to examine tracers for the spreading of water bodies in the water systems and in the environment", is not an issue under conflict of interest. Thus, we hereby declare that "The authors have no conflict of interest". In addition, "The founding sponsors had no role in the design of the study; in the collection, analyses, or interpretation of data; in the writing of the manuscript, and in the decision to publish the results".

\section{Abbreviations}

The following abbreviations are used in this manuscript:

$\begin{array}{ll}\text { SAT } & \text { Soil Aquifer Treatment } \\ \text { NWC } & \text { National Water Carrier (of Israel) } \\ \text { MBTP } & \text { Mechanical Biological Treatment Plant } \\ \text { MR } & \text { Mixing Ratio } \\ \text { SOG } & \text { Sea of Galilee } \\ \text { MCM/year } & \text { Million Cubic Meter per year } \\ \text { CBZ } & \text { Carbamazepine } \\ \text { DSP } & \text { Desalination Plant }\end{array}$




\section{References}

1. Clark, I.D.; Fritz, P. Environmental Isotopes in Hydrogeology; CRC Press/Lewis Publishers: Boca Raton, FL, USA, 1997; p. 328.

2. Drever, J.I. The Geochemistry of Natural Waters, 1st ed.; Prentice-Hall: Englewood Cliffs, NJ, USA, 1982; pp. 335-349.

3. Gat, J.R.; Dansgaard, W. Stable isotope survey of the fresh water occurrences in Israel and the northern Jordan rift valley. J. Hydrol. 1972, 16, 177-211. [CrossRef]

4. Williams, A.E. Stable isotopes tracers: Natural and anthropogenic recharge, Orange County, California. J. Hydrol. 1997, 201, 230-248. [CrossRef]

5. Kass, A.; Gavrieli, I.; Yechieli, Y.; Vengosh, A.; Starinsky, A. The impact of freshwater and wastewater irrigation on the chemistry of shallow groundwater: A case study from the Israeli Coastal Aquifer. J. Hydrol. 2005, 300, 314-331. [CrossRef]

6. Kloppmann, W.; Van Houtte, E.; Picot, G.; Vandenbohede, A.; Lebbe, L.; Guerrot, C.; Millot, R.; Gaus, I.; Wintgens, T. Monitoring reverse osmosis treated wastewater recharge into a Coastal Aquifer by environmental isotopes (B, Li, O, H). Environ. Sci. Technol. 2008, 42, 8759-8765. [CrossRef] [PubMed]

7. Alazard, M.; Boisson, A.; Marechal, J.C.; Perrin, J.; Dewandel, B.; Schwarz, T.; Pettenati, M.; Picot-Colbeaux, G.; Kloppman, W.; Ahmed, S. Investigation of recharge dynamics and flow paths in a fractured crystalline aquifer in semi-arid India using borehole logs: Implications for managed aquifer recharge. Hydrogeol. J. 2016, 24, 35-57. [CrossRef]

8. Kloppmann, W.; Vengosh, A.; Guerrot, C.; Millot, R.; Pankratov, I. Isotope and ion selectivity in reverse osmosis desalination: Geochemical tracers for man-made freshwater. Environ. Sci. Technol. 2008, 42, 4723-4731. [CrossRef] [PubMed]

9. Icekson-Tal, N.; Blanc, R. Wastewater treatment and groundwater recharge for reuse in agriculture: Dan Region reclamation project, Shafdan. In Artificial Recharge of Groundwater; Peters, J.H., Ed.; A.A. Balkama: Rotterdam, The Netherlands, 1998; pp. 99-103.

10. Lin, C.; Eshel, G.; Roehl, K.E.; Negev, I.; Greenwald, D.; Shachar, Y.; Banin, A. Studies of P accumulation in soil/sediment profiles used for large-scale wastewater reclamation. Soil Use Manag. 2006, 22, 143-150. [CrossRef]

11. Lin, C.; Eshel, G.; Negev, I.; Banin, A. Long-term accumulation and material balance of organic matter in the soil of an effluent infiltration basin. Geoderma 2008, 148, 35-42. [CrossRef]

12. Oren, O.; Gavrieli, I.; Burg, A.; Guttman, J.; Lazar, B. Manganese mobilization and enrichment during soil aquifer treatment (SAT) of effluents, the Dan Region Sewage Reclamation Project (Shafdan), Israel. Environ. Sci. Technol. 2007, 41, 766-772. [CrossRef] [PubMed]

13. Cikurel, H.; Guttman, J.; Aharoni, A. Managed aquifer recharge for agricultural reuse in Shafdan, Israel. In Book Water Reclamation Technologies for Safe Managed Aquifer Recharge; Kazner, C., Wintgens, T., Dillon, P., Eds.; IWA Publishing: London, UK, 2012; pp. 83-102.

14. Goren, O.; Burg, A.; Gavrieli, I.; Negev, I.; Guttman, J.; Kraitzer, T.; Kloppmann, W.; Lazar, B. Biogeochemical processes in infiltration basins and their impact on the recharging effluent, the soil aquifer treatment (SAT) system of the Shafdan plant, Israel. Appl. Geochem. 2014, 48, 58-69. [CrossRef]

15. Elkayam, R.; Michail, M.; Mienis, O.; Kraitzer, T.; Tal, N.; Lev, O. Soil Aquifer Treatment as Disinfection Unit. J. Environ. Eng. 2015, 141. [CrossRef]

16. Mor, R.; Michail, M.; Meron, N.; Kraitzer, T.; Elkayam, R.; Sherer, D.; Shoham, G. Groundwater Recharge with Municipal Effluent, Recharge Basins Soreq, Yavne 1, Yavne 2, Yavne 3 and Yavne 4; Annual Report; MEKOROT Water Co. Ltd.: Ramla, Israel, 2015.

17. Elkayam, R.; Aharoni, A.; Vizel-Ohayon, D.; Sued, O.; Katz, Y.; Negev, I.; Shtrasler, L.; Cytryn, O.; Lev, O. Detaching the human connection in a Soil Aquifer Treatment (SAT) system for unlimited Effluent reuse. 2017, paper in preparation.

18. Rona, M.; Gasser, G.; Negev, I.; Pankratov, I.; Elhanany, S.; Lev, O.; Gvirtzman, H. A 3-D hydrologic transport model of a water recharge system using carbamazepine and chloride as tracers. Water Resour. Res. 2014, 50, 4220-4241. [CrossRef] 
19. Gasser, G.; Rona, M.; Voloshenko, A.; Shelkov, R.; Tal, N.; Pankratov, I.; Elhanany, S.; Lev, O. Quantitative evaluation of tracers for quantification of wastewater continuation of potable water source. Environ. Sci. Technol. 2010, 44, 3919-3925. [CrossRef] [PubMed]

20. Gasser, G.; Rona, M.; Voloshenko, A.; Shelkov, R.; Lev, O.; Elhanany, S.; Lange, F.T.; Scheurer, M.; Pankratov, I. Evaluation of micropollutant tracers. II. Carbamazepine tracer for wastewater contamination from a nearby water recharge system and from non-specific sources. Desalination 2011, 273, 398-404. [CrossRef]

21. Negev, N.; Gasser, G.; Simhovitz, L.; Kraitzer, T.; Pankratov, I.; Elhanany, S.; Guttman, I.; Lev, O. The Use of Carbamazepine (CBZ) as a Tracer for a SAT System: Pilot Experiment in the Shafdan Plant; Summarizing Report MEKOROT, REP. 1647; Mekorot Water Co. Ltd.: Tel Aviv, Israel, 2015. (In Hebrew)

22. Arye, G.; Dror, I.; Berkowitz, B. Fate and transport of carbamazepine in soil aquifer treatment (SAT) infiltration basin soils. Chemosphere 2010, 82, 244-252. [CrossRef] [PubMed]

23. Cary, L.; Casanova, J.; Gaaloul, N.; Guerrot, C. Combining boron isotopes and carbamazepine to trace sewage in salinized groundwater: A case study in Cap Bon, Tunisia. Appl. Geochem. 2013, 34, 126-139. [CrossRef]

24. Dvory, N.Z.; Elad, M.; Scheuer, N.; Netzer, L.; Zurieli, A.; Livshitz, Y. Geological Cross-Sections and Base Maps of Sub-Aquifers in the Coastal Aquifer of Israel. Etgar Report No. ETHD140604, 2014. Available online: http:/ /www.water.gov.il/HEBREW/PROFESSIONALINFOANDDATA/DATA-HIDROLOGEIME/ Pages/atlas-beach.aspx (accessed on 4 December 2016).

25. Goren, O.; Burg, A.; Gavrieli, I.; Negev, I.; Guttman, I.; Kraitzer, T.; Kloppmann, W.; Guerrot, C. Multi-Isotope Tracing of Groundwater Flow, Solute Transport and Redox Reactions in a Large Scale Water Reclamation System; French-Israeli Bi-Lateral Scientific Research, Final Report; Mekorot Water Co. Ltd.: Tel Aviv, Israel, 2011.

26. Kloppmann, W.; Negev, I.; Guttman, J.; Guerrot, C.; Flehoc, C.; Pettenati, M.; Goren, O.; Burg, A. Man-made water cycles: Isotope tracing of desalinated seawater through water supply, sewage and groundwater. In Proceedings of the Goldschmidt Conference 2012, Montreal, QC, Canada, 24-29 June 2012.

27. Epstein, S.; Mayeda, T. Variation of ${ }^{18} \mathrm{O}$ content of waters from natural sources. Geochim. Cosmochim. Acta 1953, 4, 213-224. [CrossRef]

28. Oshumi, T.; Fujini, H. Isotope exchange technique for preparation of hydrogen gas in mass spectrometric D/H analysis of natural waters. Anal. Sci. 1986, 2, 489-490.

29. Gat, J.R.; Shemesh, A.; Tziperman, E.; Hechi, A.; Georgopoulos, D.; Basturk, O. The stable isotope composition of waters of the eastern Mediterranean Sea. J. Geophys. Res. 1996, 101, 6441-6451. [CrossRef]

30. Avisar, D. Salinization Processes and Aquifer Interconnections in the Southeastern Coastal Plain of ISRAEL. Ph.D. Thesis, Tel Aviv University, Tel Aviv, Israel, 2001.

31. Schilman, B.; Teplyakov, N.; Gavrieli, I. Identification of Nitrate Contamination Sources in Groundwater Using Nitrogen and Oxygen Isotopes in Nitrate: Wadi Kelt-Jericho Area as a Case Study; REP. GSI/25/2004; GEO SUR ISR: Jerusalem, Israel, 2004.

32. Siebert, S. Saisonale Chemische Variationen des See Genezareth, Seiner Zuflusse und deren Ursachen. Ph.D. Thesis, Freie Univeritat, Berlin, Germany, 2006. (In German)

33. Yechieli, Y.; Kafri, U.; Sivan, O. The inter-relationship between coastal sub-aquifers and the Mediterranean Sea, deduced from radioactive isotopes analysis. Hydrogeol. J. 2009, 17, 265-274. [CrossRef]

34. Burg, A.; Talhami, F. The Yarkon-Taninim Aquifer Monitoring Project; Chemical and Isotopic Compositions in New Monitoring Wells and Other Selected Wells, Sixth Year Report; REP. GSI July 2013; Geo SUR ISR: Jerusalem, Israel, 2013; p. 22. (In Hebrew)

35. Stiller, M.; Rosenbaum, J.M.; Nishri, A. The origin of brines underlying Lake Kinneret. Chem. Geol. 2009, 262, 293-309. [CrossRef]

36. Cappa, C.D.; Hendricks, M.B.; DePaolo, D.J.; Cohen, R.C. Isotopic fractionation of water during evaporation. J. Geophys. Res. 2003, 108, 13:1-13:10. [CrossRef]

37. Ayalon, A.; Bar-Matthews, M.; Schilman, M. Rainfall Isotopic Characteristics at Various Sites in Israel and the Relationships with Unsaturaten Zone Water; REP. GSI/16/04; GEO SUR ISR: Jerusalem, Israel, 2004.

38. Schiavo, M.A.; Hauser, S.; Povinec, P.P. Stable isotopes of water as a tool to study groundwater-seawater interaction in coastal south-eastern Sicily. J. Hydrol. 2009, 364, 40-49. [CrossRef]

(c) 2017 by the authors; licensee MDPI, Basel, Switzerland. This article is an open access article distributed under the terms and conditions of the Creative Commons Attribution (CC BY) license (http://creativecommons.org/licenses/by/4.0/). 